\title{
"A Strange Survival": The Rev. W.A. Wigram on the Assyrians before and after World War I
}

\author{
Heleen Murre-van den Berg
}

\section{1 \\ Introduction}

One of the most prolific writers on the Assyrians of the Church of the East was the Anglican missionary William Ainger Wigram (1872-1953), who worked for the Archbishop of Canterbury's Mission to the Assyrian Christians from 1901 to 1912. His range of well-illustrated books on the history of the Church of the East and the life of the contemporary Assyrians are considered to have played an important role to bring the plight of the Assyrians to the attention of the general public, especially in Great Britain. Wigram became most famous for his post-war pamphlet entitled Our Smallest Ally, in which he lauded the military contribution of the Assyrians to the British and Allied war-efforts in the Kurdish region. Together with the Russians and Armenians, they took up arms against the Ottoman armies after it became clear that the Ottomans were on their way to expulse all Christians from Eastern Turkey. However, the fight for Kurdistan was lost and many of the Assyrians from the Hakkari Mountains ended up in a British refugee camp in Baquba, near Baghdad. In Our Smallest Ally Wigram pressed home British responsibility for the future of this vulnerable people that had been caught up by events beyond their control. The pamphlet's frank criticism of British politics in Iraq made it an important source for contemporary and later anti-colonial Assyrian historiography, even if the pamphlet, like Wigram's other works, was firmly rooted in British imperial and colonial perceptions of the world.

This may come across as a pretty straightforward way of a missionary acting as an advocate for a people with whom he became involved over the years. A closer look, however, at Wigram's publications suggests that his advocacy in many respects was different from most of his missionary colleagues of the time. Most obviously, Wigram's activities were further removed from the struggles of day-to-day relief work that brought so many of the American missionaries to their pleas for humanitarian action. Their experiences led them to become actively engaged in humanitarian aid, in connection with but also independent 
of missionary organizations and missionary aims. ${ }^{1}$ It is this turn to humanitarian action in the context of war, massacre and displacement that is the main topic of the current volume. What I intend to bring to the fore in the current contribution is that this turn to active and secularized humanitarianism was not the only option open to missionaries. Anglican missionaries in general and Wigram in particular chose a different route, a route that on the one hand was intricately connected with British colonial interests in the region, and on the other with ecumenical and scholarly concerns. Nevertheless, I will argue that despite their different emphases, Wigram's publications are as much part of the turn away from conversionist and civilizational missions as the activities and accompanying publications of his mostly American colleagues.

\section{The Anglican Missions in Hakkari, Persia, Mesopotamia}

By the time William Wigram became a part of the Anglican mission, the Archbishop of Canterbury's Mission to the Assyrian Christians already had a long history. The mission's (and Wigram's) biographer, J.F. Coakley, traces its beginnings to early contacts between Anglican clerics such as George Percy Badger in the 1840 s and the Church of the East in the Eastern provinces of the Ottoman Empire and northwestern Iran. The Archbishop of Canterbury's mission was established in Urmia (Persia) in 1886. Like the earlier established Protestant (ABCFM and later Presbyterian) and Catholic (Lazarist and Catholic) missions, the Anglicans operated their own press that published mostly educational and liturgical books. After also Russian and German, Scandinavian and American Lutheran missionaries arrived at the scene, the Assyrian community of the Urmia region could choose from a surprisingly high number of

1 Keith David Watenpaugh, Bread from Stones: The Middle East and the Making of Modern Humanitarianism (Berkeley: University of California Press, 2015) underlines the importance of American missionary organizations and individuals in understanding the initiatives as well as the ambiguities of modern day humanitarian actions, including ongoing racialized thinking; see also Miriam Ticktin's review of Watenpaugh, "Humanity as Concept and Method: Reconciling Critical Scholarship and Empathetic Methods," Comparative Studies of South Asia, Africa and the Middle East 37, no. 3 (2017): 608-613. No in-depth study has been written about the American missionary relief activities for the Assyrians during the war, but most studies of this mission (see n. 2 and 4) pay attention to their work. One of the most impressive memoirs of missionary humanitarianism among the Assyrians is that by Mary Lewis Shedd on her husband: The Measure of a Man: The Life of William Ambrose Shedd, Missionary to Persia (New York: George H. Doran, 1922). 
missionary activities, albeit that the Assyrians of the hard-to-travel Hakkari Mountains generally remained far removed from the more intense engagement with the missions that took place in the Urmia plain. In Mosul and its environs, the mostly Catholic (French Dominican) missionaries dominated ecclesial and educational work among Assyrian as well as Chaldean, Syriac Orthodox, and Syrian Catholic communities. ${ }^{2}$

Over the years, the Anglicans fostered a reasonably good relationship with the leadership of the Church of the East, especially because they, different from the Presbyterian, Lazarist, and Dominican missions, had no intention to convert individual Assyrians to the Anglican church or to forge a union between the Church of the East and Anglican church. They considered the Church of the East a sister church that certainly was in need of education and reform, but was also to be respected as an independent local church. It was upon their request for support, especially concerning the education of the clergy and the printing of liturgical books that the Anglicans offered their service-a kind of mission that dovetailed with the ecumenical and liturgical concerns of the Archbishop of Canterbury. ${ }^{3}$

Because of these converging aims, the Anglican mission was able to maintain good relationships with the ecclesial head of the Church of the East and his family, first patriarch Mar Shimun XVIII Ruel (186o-1903), then Mar Shimun XIX Benyamin (1903-1918). For most of the period under discussion, the hereditary patriarch resided in Qodshanis, in the Ottoman part of the Hakkari Mountains, where he also acted as the tribal leader of the Assyrian mountain clans, negotiating their internal disputes as well as representing the Assyrian case with the Kurdish leaders of the region. From the winter of 1887/88 till his death in 1910, William Henry Browne, one of the pioneer Anglican missionaries, resided in Qodshanis rather than in the Persian city of Urmia where most of his colleagues lived. In addition to maintaining a small medical dis-

2 On the Anglican mission in Urmia, see J.F. Coakley, The Church of the East and Church of England: A History of the Archbishop of Canterbury's Assyrian Mission (Oxford: Clarendon Press, 1992); on the other missions, see John Joseph, The Modern Assyrians of the Middle East: Encounters with Western Christian Missions, Archeologists, and Colonial Powers, SCM 26 (Leiden: Brill, 20oo, revised); Heleen Murre-van den Berg, From a Spoken to a Written Language: The Introduction and Development of Literary Urmia Aramaic in the Nineteenth Century, Publication of the "De Goeje Fund" 28 (Leiden: NINO, 1999); Adam Becker, Revival and Awakening: Christian Mission, Orientalism, and the American Evangelical Roots of Assyrian Nationalism (1834-1906) (Chicago: Chicago University Press, 2015); Thomas S.R. O'Flynn, The Western Christian Presence in the Russias and Qājär Persia, c.1760-c.187o, SCM 47 (Leiden: Brill, 2017).

3 Coakley, The Church of the East, chapters vi and viI. 
pensary, Browne taught the children of the extended patriarchal family, including patriarch-to-be Benyamin and his sister Surma.

In 1897, Russian Orthodox missionaries intensified earlier attempts to bring the Assyrians into the Eastern Orthodox fold. With the Russian civil and military presence in the region, this was a more attractive partner to the traditionalist Assyrians than the Anglicans. Though the latter expressed some misgivings over this quick change of sympathies, on theological and historic grounds they felt compelled to leave the field to their ecumenical Russian partners and moved their school to Van, on the Ottoman side of the Hakkari mountain range, where they continued to take in Assyrian students. In 1910, the school was moved to the village of Bebaydi in today's North Iraq, where it had to be closed a few years later when the Anglicans left at the outbreak of the war. After the war, the mission house in Bebaydi briefly served as the home of the displaced patriarchal family. During the war years and after, the Anglican mission committee in the England collected funds to support the Assyrians in the hardship that followed upon expulsion and displacement, first from the Hakkari Mountains to Urmia, then from Urmia to Hamadan and the refugee camps in Baquba and Mindan. The money that was collected in England found its way not only to the Assyrians in British-supervised camps, but also to those who started to reestablish their lives in North Iraq and later in Syria. During the war, books and pamphlets, such as The Death of a Nation, or the Ever Persecuted Nestorians or Assyrian Christians by Abraham Yohannan (New York, 1916), brought the plight of the Assyrians under the attention of the British public. ${ }^{4}$

After the war, the mission did not re-establish itself among the Assyrians of Iraq or Persia, but remained involved in the situation of the Assyrians. The post-war Archbishops of Canterbury, Randall Davidson (1903-1928) and Cosmo Gordon Lang (1928-1942), were in regular contact with the British High Com-

4 Coakley, The Church of the East, 338, 353. On the Assyrians during the war, see (in addition to the sources mentioned in n. 2), Florence Hellot-Bellier, Chroniques de massacres annoncés: Les Assyro-Chaldéens d'Iran en du Hakkari face aux ambition des empire, 1896-1920 (Paris: Geuthner, 2014); David Gaunt, Massacres, Resistance, Protectors: Muslim-Christian Relations in Eastern Anatolia during World War I (Piscataway, NJ: Gorgias Press, 2006); Sargon George Donabed, Reforging a Forgotten History: Iraq and the Assyrians in the Twentieth Century (Edinburgh: Edinburgh University Press, 2015). On the Baquba camp, see H.H. Austin, The Baqubah Refugee Camp: An Account of Work on behalf of the Persecuted Assyrian Christians (London: The Faith Press, 1920); H. Mueller, "The League of Nations, A-Mandates and Minority Rights during the Mandate Period in Iraq (1920-1932)," in Modernity, Minority, and the Public Sphere: Jews and Christians in the Middle East, eds. S.R. Goldstein-Sabbah and H.L. Murre-van den Berg, LSIS 4, (Leiden: Brill, 2016), 258-283; Laura Robson, States of Separation: Transfer, Partition, and the Making of the Modern Middle East (Stanford: University of California Press, 2017). 
missioners of Mesopotamia about the Assyrians and their resettlement. They also kept in contact with Dr. Panfil, an Episcopal missionary from the United States who had been sent to support the Assyrians of Iraq. Anglican educational work in the Jazeera region of French Mandate Syria, where some of the Assyrians had ended up after 1933, did not prosper. After the contacts with and aid to the Assyrian Church of the East were taken over by the Anglican bishopric of Jerusalem (and supported by the Anglican Jerusalem and East Mission), the mission committee in England continued to support the patriarchal family, first in Bebaydi, then on Cyprus and later in England, until the various members of the family moved to the United States in the 1940s. ${ }^{5}$

\section{Wigram and His Writings}

William Ainger Wigram was born in 1872 in a lower-gentry vicar's family in Furneaux Pelham. He enjoyed the benefits of a solid classical education, with years at King's School in Canterbury and at Trinity Hall in Cambridge before he became an Anglican cleric. ${ }^{6}$ After ordination in 1897 he worked at two parishes before he joined the mission in 1902 where he was assigned to oversee the ordinands' school in Van. ${ }^{7}$ At the beginning of his second five-year term he was appointed as the head of the mission and as such was responsible for building a new mission post in Bebaydi in 1910. Wigram left the mission in 1912 to become a chaplain in Constantinople, where he was interned during in the war. Before he could make his way home when the war was finished, he was reposted to Iraq to assist the British colonial officers in the resettlement of displaced Assyrians in Baquba. After resettlement schemes failed in 1922, Wigram left for another stint in Constantinople, although he returned to Iraq for a brief visit in 1928. He continued his ecclesial career first in Greece (1922-1926), then on Malta (1928-1936). His last years he spent in England where he died in Salisbury in 1953. Over the years he remained keenly interested in Assyrian affairs, publishing and advocating for the Assyrians and the patriarchal family, and never quite loosing contact with them.

5 Coakley, The Church of the East, chapter viI.

6 In $19 \circ 9$ he received the Doctor of Divinity (D.D. Lambeth) degree from the Archbishop of Canterbury, acknowledging his scholarly work in service of the church; in 1919 or 1920 he received a regular Cambridge Doctor of Divinity (B.D.) degree, see n. 15 .

7 The following is based on Coakley's The Church of the East and on a concise biography by the same author: J.F. Coackley, "Wigram, William Ainger (1872-1953)," in Oxford Dictionary of National Biography, ed. Lawrence Goldman (Oxford: OUP, 2004). Available via http://www .oxforddnb.com/view/article/58374. 
Wigram started publishing on Assyrian matters during his second term at the mission, with a position paper presented to the Lambeth Conference of 1908. One of the important themes of this international intra-Anglican conference concerned ecumenical relations and intercommunion with Eastern Churches. Wigram contributed a paper on the Church of the East, under the title The Doctrinal Position of the Assyrian Church. While at the time the deliberations did not lead to any concrete steps, Wigram's paper argued that the supposedly heretical position of the so-called "Nestorian" Church could be reinterpreted more congenially as being much closer to what the Anglicans and Eastern Orthodox considered the orthodox view. Although the Anglican missionaries among the Assyrians differed in their exact views on this, overall the mission tended to attribute the differences between Anglican and Church-ofthe-East theology to matters of translation and historical interpretation rather than to deep-seated doctrinal differences. Wigram consistently argued that the Church of the East was an independent and orthodox Christian church and thus advocated full communion. ${ }^{8}$

His views on the history of the Assyrian Church were further expounded in his second book, An Introduction to the History of the Assyrian Church: Or the Church of the Sassanid Persian Empire, 100-640A.D. which was published in 1910. This book can be read as a fuller exposition, for a wider public, of his views on the early history and doctrinal position of the Church of the East. ${ }^{9}$ His choice to again use the epithet "Assyrian" in the title underlines this: in the preface he rejects other current names for this church as misleading to the English reader, by referring to geographical areas not consistent with modern names and regions ("Syrian", "Persian") or because "Nestorian' has a theological significance which is not justified". "Assyrian", on the contrary, "has at least the merit of familiarity to most friends of the Church to-day". ${ }^{10}$ His second full-length book on the Assyrians was published in 1914, entitled The Cradle of Mankind: Life in Eastern Kurdistan. ${ }^{11}$ This travelogue contains a lively description of contemporary life in the Eastern provinces of the Ottoman Empire and the adjacent provinces of Urmia, introducing Assyrian customs against the background of the wider population. Wigram collaborated with his brother

8 Coakley, The Church of the East, 285, 296-297.

9 This sympathetic reading of the Church of the East's Christology is clear from the book as whole, and is explicated and brought to the present in ch. XII, 'Official Christology of the Assyrian Church,' W.A. Wigram, An Introduction to the History of the Assyrian Church: Or the Church of the Sassanid Persian Empire, 100-640 (London: SPCK, 1910), 265-298.

10 Wigram, An Introduction, vii-viii.

11 W.A. Wigram, The Cradle of Mankind: Life in Eastern Kurdistan (London: Adam \& Charles Black, 1914); Second edition (London: Adam \& Charles Black, 1922). 
Edgar T.A. Wigram who was a travel writer in his own right. All sketches and photographs in the volume are attributed to Edgar, but to what extent he also contributed to the text remains unclear.

After William Wigram's post-war travel to Iraq, he authored two small pamphlets which dealt with what must have been the two most pressing issues on his mind. The first, Intercommunion with the Assyrian Church, addressed the ecumenical relations between the Assyrians and the Anglican Church, the second, Our Smallest Ally, addressed the political relations between the Assyrians and Great Britain. Both pamphlets were published in England in 1920, the second also simultaneously in the United States. In the first, he revisits and restates his earlier position on the fundamental orthodoxy of the Church of the East, arguing for full and speedy recognition of the Assyrian church as a sister church. ${ }^{12}$ The second pamphlet is the one that is best known today, posted on Assyrian websites like Atour.com and often referred to in discussions. In it, Wigram argues for ongoing British involvement with the Assyrians, because of the valuable service they rendered to the British during the war as well as their potential in pacifying Iraq: "Can Great Britain, now that she is responsible for order in the country, afford to neglect so valuable a military asset as this nation has proved itself to be?"13

In 1922, The Cradle of Mankind was republished with two extra chapters that largely overlap with Our Smallest Ally, pressing home the same point of British obligation towards the Assyrians. In that same year, the pamphlet The Assyrian Settlement was published. ${ }^{14}$ In 1923, he published his Cambridge dissertation The Separation of the Monophysites on the history of what today is usually called the Miaphysite tradition, especially that of the Syriac Orthodox Church. ${ }^{15}$ In 1929, he published The Assyrians and their Neighbours. All major

12 "Intercommunion with the Assyrian Church by William Ainger Wigrim, D.D.," Project Canterbury, accessed March 30, 2018, http://anglicanhistory.org/orthodoxy/wigram/assyrianı 920.html.

13 W.A. Wigram, Our Smallest Ally: A Brief Account of the Assyrian Nation in the Great War (London: SPCK; New York: Macmillan, 1920), 57. This was written after he worked in the Baquba refugee camp; the pamphlet includes an introduction by H.H. Austin, the British officer in charge of the camp. Similarly, Wigram, The Cradle, and ed., 451. On the military aspect of Assyrian identity, see also Heleen Murre-van den Berg, "Writing Assyrian History: The Military, the Patriarch and the British in Yaqu bar Malek Ismael's Assyrians in Two World Wars (Tehran 1964)," in Sayfo 1915: An Anthology of Essays on the Genocide of Assyrians/Aramaeans during the First World War, eds. Shabo Talay and Soner O. Barthoma, Gorgias Eastern Christian Studies 5o (Piscataway: Gorgias Press, 2018), 213-230.

14 Unfortunately I have been unable to find a copy of this publication.

15 Its introduction relates how he originally submitted a dissertation on the same topic in 1914, also at Cambridge. It was accepted, but Wigram was not able to finalize the proced- 
themes return here, with the history of the Assyrians situated against the background of British Iraq where the brave Assyrians should find new homes after the devastations of war.

That this was not to come to pass, at least not in the way Wigram envisaged it, became clear in 1933, not long after the British had been forced to give up Mandate rule in Iraq. The Semele massacre of recently disarmed Assyrians brought to light the antagonisms that had built up against the refugee Hakkari Assyrians in Iraq, resulting in the expulsion of those that survived to French-ruled Syria or further afield. ${ }^{16}$ In these years Wigram continued to advocate the sake of the Assyrians, but in such a way that he lost his clout with the Archbishop of Canterbury-delicate as these matters were in relation to ongoing British interests in Iraq. While he continued to publish journal articles on the Assyrians, his only further major publication was related to another of his lifelong interests, Hellenic Travel: A Guide (1947). ${ }^{17}$

\section{$4 \quad$ The Cradle of Mankind}

As his early publications indicate, the first of Wigram's interests, befitting an Anglican missionary, was that into the ecclesial history and contemporary religious practices of the Church of the East. As noted above, like his fellowmissionaries he was motivated to paint the case of Assyrian orthodoxy as unambiguously as possible, for as large a public as possible. While this served ecumenical interests, especially of those in Great Britain that advocated closer cooperation with the Eastern Orthodox Churches, it also endangered cooper-

ure because of his wartime incarceration in Istanbul. After the war, both the manuscript and his notes had been lost. Wigram rewrote the dissertation and re-submitted it to a different committee, which again accepted it. With the help of F.C. Burkitt, who was also part of the committee, it was published in 1923. Remarkably, Burkitt reviewed it (largely positively) in The Journal of Theological Studies 26, no. 104 (1925): 427-431, reading it as an address not only to a Western public, but also to the patriarch of the Church of the East, in order to smooth relations between the two Syriac churches. Burkitt, 428 .

16 On the Semele massacre, see Donabed, Reforging a Forgotten History; R.S. Stafford, The Tragedy of the Assyrians (London: George Allen \& Unwin LTD, 1935); Khaldun S. Husry, "The Assyrian Affair of 1933," Int. J. of Middle East Studies 5, no. I (1974): 161-176, and no. II: 344-36o; Sami Zubaida, "The Fragments Imagine the Nation: The Case of Iraq," Int. J. of Middle East Studies 34, no. 2 (2002): 205-215; H.L. Murre-van den Berg, "Light from the East (1948-1954) and the De-Territorialization of the Assyrian Church of the East," in Religion beyond its Private Role in Modern Society, eds. W. Hofstee and A. van der Kooij (Leiden: Brill, 2013), 115-134. See also Robson, States of Separation.

Coakley, The Church of the East, 356-6oo. 
ation with the same churches, because many were not too keen on admitting Assyrians to their fold — or at least demanded changes in their liturgy that the Anglican missionaries had been hesitant to put pressure on. ${ }^{18}$ Notably, according to Wigram the main reason for the ongoing schism and mutual misunderstandings does not lie in Church-of-the-East theology as such, but in its failed attempts to harmonize "Western" and "Oriental", or better "Greek" and "Semitic", modes of thinking, rather than understand and value each of them for their own sake. According to him, separation and distinction are to be preferred, rather than mixing and confusing. ${ }^{19}$

His intimate knowledge of Assyrian life led him to describe in lively detail ecclesial and religious practices that earlier scholars tended to ignore. He notes "magic", i.e., practices with amulets and other objects, "aboriginal tree-worship", "faith-healing" of "lunatics" in enclosed quarters, rituals at saints' shrines to further pregnancies, and animal sacrifice at yearly festivals. ${ }^{20}$ Though there is always a hint of condescension, Wigram writes with sympathy about the practices that he thought served a purpose in the religious world of the Assyrians. The same mix of condescension and sympathy suffuse his description of similar religious practices among Yezidis, Jews, and Muslims. Although the superiority of Christianity is never questioned, Wigram acknowledges that religious practice is much the same among all of those in the region. ${ }^{21}$ This is one of the reasons why it is not European Christianity that should convert Muslims, but rather "Christianity preached as the Asiatic faith which it really is". To what extent these vernacular religious practices are part of that "Asiatic faith" is left unsaid, but Western missions, Wigram asserts, should primarily be about "uplifting of the native Christians", not about converting Muslims. ${ }^{22}$

However, a careful reading of The Cradle of Mankind alongside An Introduction suggests that Wigram's interest in the Assyrians was grounded not

18 Coakley, The Church of the East, 134-144. On Wigram's mostly negative evaluation of the Russian missions in Urmia, see Coakley, The Cradle, 203, 208.

19 Wigram, An Introduction, 266; Wigram, The Cradle of Mankind, 86.

$20 \quad$ Wigram, The Cradle of Mankind, 205, 306-307, 326-329, 335-337.

21 See especially his description of the Yezidis, the so-called "Devil-worshippers". Wigram, The Cradle of Mankind, 87-110.

22 Wigram, The Cradle of Mankind, 205. This cautious view on "Muslim missions" was held against him in an otherwise positive review of The Cradle of Mankind by Margaret G. Brooke, in International Review of Mission 4, no. 1 (1915): 158-159. A similar point was made by Ruth Rouse who reviewed the volume for The Muslim World 4, no. 4 (1914): 434: "The book is neither a missionary book nor a book on Islam, except incidentally, but the authors hold strong views on the need for the regeneration of the Oriental Churches as a preliminary to the evangelisation of the Moslim world." 
only in his ecumenical ethos, but also in an interpretation of the region as one of the origins of Western civilization, "the very fons et origo of our IndoEuropean ancestors" - indeed, the "cradle" from which European civilization took much of what makes it important-while at the same time being a living illustration of Europe's past. ${ }^{23}$ This "living illustration" consisted of the detailed ethnography of life in Kurdistan embedded in historical and geographical excurses. ${ }^{24}$ In this, Wigram and his brother were very much part of the emerging evolutionist views of the time. These not only concerned Darwinian views of the history of biological life in general and humans in particular, but also the evolution of culture as proposed in the first works of the emerging field of Anthropology. The work of Edward Burnett Tylor in particular may have inspired Wigram, in its combination of historical, linguistic, biological, and ethnographic approaches. ${ }^{25}$ In turn, these evolutionist anthropological models also strongly influenced the interpretation of history more generally, and Wigram shared Tylor's idea of the evolution of "civilizations". Northwestern European civilization, rooted in Greek and Latin classical culture was considered the most evolved, with others, as yet, lagging behind for historical, geographical, or cultural reasons. This evolutionary view, therefore, naturalized European and British civilizations as the most suited to rule the world. At the same time, it allowed for campaigning for modernization and development of those considered more backward, because in the end all human culture originates from the same source, and thus all are able to reach the same level. Within the confines of this rather broadly accepted civilizational scheme, Wigram started to construct a well-documented "classical" history for the Assyrians harking back to pre-Roman and pre-Greek days, thereby allowing them to be seenand see themselves - as one of the sources rather than a later offshoot of the great river of civilization. ${ }^{26}$

23 Wigram, The Cradle of Mankind, vii-viii.

24 This was particularly liked by the reviewers, see (the anonymous) P.M.s. in Journal of the Royal Asiatic Society of Great Britain and Ireland (1914): 1140-1141 and the anonymous reviewer in the Bulletin of the American Geographical Society 47, no. 3 (1915):219, who notes that "the authors find great interest in the society, no matter what its creed, and draw parallels with the Highlanders of Scotland."

25 Edward Burnett Tylor, Anthropology: An Introduction to the Study of Man and Civilization (London: Macmillan and Co., 1881/1896).

26 On this topic more broadly, see Mark Bradley, ed., Classics and Imperialism in the British Empire (Oxford: OUP, 2010). Note that such classical pedigrees were developed and appropriated by many other groups at the time, most explicitly so among the Maronites, see Asher Kaufman, Reviving Phoenicia: The Search for Identity in Lebanon (London \& New York: I.B. Tauris, 2002). 
This evolutionary reading of the Middle East sits comfortably with older Orientalist tropes about the region, and the Wigrams added their share of stereotypes in describing the different groups characterized by language and religion. Christians usually are seen as higher on the civilizational scale than Muslims, while what in European eyes are considered negative traits (internal divisions and population mixture) are interpreted as the negative results of longstanding Turkish rule. ${ }^{27}$ Taking these negative aspects of Turkish rule as inevitable, the Wigrams' Orientalist gaze mostly focusses on the romantic and "picturesque" aspects of it all, comparing life in the Kurdish mountains to that of the Scottish highlands: rough and dangerous, but also strong, chivalrous, and amenable to improvement and progress. ${ }^{28}$

Like in other works describing the Middle East for a Christian public at home, Wigram and his brother exploit specific Christian interpretations of the region. The "cradle of mankind" thus overlays and expands earlier missionary and theological interpretations of the region as part of the wider "Holy Land". 29 Like in the case of Palestine, this centered on the region's purported connection to biblical geography, including the location of "Paradise" or the "Garden of Eden", Noah's Ark, the land of Israel's captivity, and the home town of the prophet Nahum. It also includes references to customs and tools that hardly altered "since the days of Abraham". ${ }^{30}$ The ambiguities of mixing biblical and classical allusions are exemplified by the sketch opposite the title page. Here an image of a stark gorge in the Hakkari Mountains is entitled "The River of Eden", followed by the actual modern name of the gorge. There is no attempt to prove that this actually is one of the rivers that Genesis tells us flew out of Paradise, and therefore the associations elicited by the image plus caption may as well interpreted as an indication of the story of universal human origins in the rugged mountains of Kurdistan rather than that of a precise location of the biblical narrative. ${ }^{31}$

27 Wigram, The Cradle of Mankind, 8o-81.

28 E.g., Wigram, The Cradle of Mankind, v, viii, 67, 330, 343, 194-195; Wigram, The Assyrians, 208.

29 Heleen Murre-van den Berg, "William McClure Thomson's The Land and the Book (1859): Pilgrimage and Mission in Palestine," in New Faith in Ancient Lands: Western Missions in the Middle East in the Nineteenth and Early Twentieth Centuries, ed. Heleen Murre-van den Berg, scm 32 (Leiden: Brill, 20o6), 43-63.

30 Wigram, The Cradle of Mankind, vii, 22-23, 26, 81-82, 84-85, 116-117, 187, 235, 264, 304, 335337 .

31 Wigram, The Cradle of Mankind, ii: "The River of Eden (The Zab entering the Tyari Gorges). The view downstream from the mouth of the Ori valley, a little above Tal. The distant snow peak is Ghara Dagh on the southern side of Tkhuma." 
This evolutionist and universalist context puts Wigram's detailed attention for popular religious practices in a different perspective. The way these are described not necessarily reflect the interest of the missionary reformist who seeks to eradicate (slowly if needed) the remains of pre-Christian superstitions among his flock, but more those of an anthropologist who sees these religious beliefs and practices as authentic be it outdated forms of religion, "fossils" that teach historians and theologians alike what used to be shared among earlier peoples all around the world, including those of Europe. According to Wigram, the region is particularly rich in such fossils: "Nearly every form of religion which has yet been known to man seems at some time or other to have struck root in the soil of Mesopotamia; and there are but few of the number that have left no stumps or fossils to remind us of the days when they were yet flourishing in their pride."32 And further on: "No fossiliferous strata preserve the forms of past ages more thoroughly than does the corporate mind of the living East; though it is often hard to extract the fossils, and harder to ascertain their true significance". 33

\section{Our Smallest Ally?}

Among these fossils whose "true significance" needs to be discovered, the Assyrian Church takes pride of place. The title page, opposite the "River of Eden" photograph, features the vignette of a priest in profile, which is repeated on the cover of the book. ${ }^{34}$ Though the image seems designed not to refer to a specific person, the priest later on in the volume is identified as "the late Qasha Khoshaba, who might have been a reincarnation of Sargon". ${ }^{35}$ The image on the title page thus not only gives away the Assyrians as the main topic of The Cradle, but it also links their contemporary importance to what many believed to be their forbears, the Assyrians of old. Wigram, different from some of his missionary colleagues, was among the early adopters of the name "Assyrian" for the Christians of the Church of the East. ${ }^{36}$ Nevertheless, in his earlier pub-

\footnotetext{
32 Wigram, The Cradle of Mankind, 88.

33 Wigram, The Cradle of Mankind, 233-234.

34 The en profile image is another implicit reference to the early anthropology of Edward Tylor, cf. Tyler, Anthropology, 2.

35 Wigram, The Cradle of Mankind, 112, notes (similarly, 276); note that the same (now full) portrait, with a matching image of King Sargon from an ancient Assyrian image, is given in W.A. Wigram, The Assyrians and their Neighbours (London: G. Bell \& Sons, 1929), 179 .

36 For the early history of the usage of this term, see Becker, Revival and Awakening. The Arch-
} 
lications he remained cautious: in An Introduction the only explicit argument for its use is the fact that other names are even less appropriate, though "there is no historical authority for this name". ${ }^{37}$ In The Cradle he introduces the issue lightly, referring to "their own traditions" in which Assyrians claim that they are the descendants of "the ancient Assyrians" rather than making the case for it himself. ${ }^{38}$ Only the use of the image of priest Khoshaba with its reference to Sargon can be read as an implicit argument in favour of the Assyrian identification. ${ }^{39}$

Almost twenty years later, when The Assyrians and their Neighbours was published, things had changed. In Wigram's book of 1929 the identification of the modern-day Assyrians with the ancient Assyrians is very explicit, circling around the concept of "stock" - a term which he used only a few times in The Cradle in the sense of referring to a group with common ancestry, mostly parallel with "race". ${ }^{0}$ In The Assyrians racial thinking had become one of the main themes, most explicitly so in the first chapter in which "the national stocks in Mesopotamia" are being carefully distinguished from each other and organized hierarchically, with the Assyrians on top as one of the most ancient and honorable in the region, and Arabs and Kurds further down the scale, setting the scene for a racialized interpretation of the inhabitants of the region. ${ }^{41}$ In a later chapter, he discusses the proposed link between the ancient and modern Assyrians more extensively, putting forward linguistic, physical, and ethnographic arguments, in line with Tylor's anthropological methods, though never quite committing himself to it fully. ${ }^{42}$ Though putting himself squarely at the side of those who believe in an unbroken line between the Assyrians of old and those of the present day, he admits that contemporary Assyrians are not of "unmixed blood", even if their strict marriage laws allowed them to keep "a purity of blood

bishop of Canterbury's mission used this name almost from the beginning, see Coakley, The Church of the East, 65, 147-148, 285 .

37 Wigram, An Introduction, vii.

38 Wigram, The Cradle of Mankind, 112.

39 Wigram, The Cradle of Mankind, 344-346 (about Mosul/Nineveh).

40 At least one reviewer, J. Lewy, in Orientalistische Literaturzeitung 35 (1932): 576 reacted negatively to this "Assyrian identification", although he liked the final chapters on the current state of the nation.

41 Wigram, The Assyrians, vii, 1-14. Note Wigram's rather critical stance towards the Armenians, perhaps reflecting views among Assyrians and Westerners in Eastern Turkey at the time, suggesting that some of the Armenian parties were at least partly to be blamed for the accusations of disloyalty from the Turkish government. Some of his accusations remind the reader of anti-Semitic tropes, cf. The Assyrians, 9 ("Unable either to command or obey, the Armenian was forever intriguing against ...").

Wigram, The Assyrians, 178-193; Tylor, Anthropology, $15_{2} \mathrm{ff}$. 
not known in the West", combining his understanding of a somewhat messy historical past with his preference for pure and unmixed cultures. ${ }^{43}$ Wigram thus provides the Assyrians with a deep historical pedigree, a valid claim on lands in Iraq and Eastern Turkey, and a well-described ethnoreligious identity that is as romantic and picturesque as it is military and imperial, on a par with other nations of the world. And so the Assyrians become worthy objects for the attempts of the British Mandate government in cooperation with the League of Nations to find them new homes. ${ }^{44}$ These resettlement plans, part of a much larger attempt of the colonial powers to redraw boundaries and resettle populations towards clearly identifiable and distinct nations conforming as much as possible to the ideal of religiously, linguistically, and ethnically homogeneous populations. ${ }^{45}$ Whereas Wigram did not invent the Assyrians as a separate group, his writings contributed significantly in elaborating and solidifying what Assyrian identity might mean not only for Assyrians on the ground and abroad, but also for the British public as much as its policy makers, colonial rulers, and military.

According to Wigram, one aspect of that newly emerging identity is the Assyrians' enduring global importance in the "museum of ethnology and of religious science" that is this land "with six thousand years of continuous history". ${ }^{6}$ As "a strange survival" their "ancient and fossilized Church" has "preserved ecclesiastical rites and ceremonies which have either perished altogether elsewhere, or else have survived only in almost unrecognizable form". ${ }^{47}$ These older forms of religion and church may remind Christians and others everywhere of our common origins, "human nature [being] much the same all the world over" ${ }^{48}$ However, in the work of Tylor, in which such fossilized sur-

43 Wigram, The Assyrians, 167-168, 179, 184-185; see also earlier Wigram, The Cradle of Mankind, 83-84.

44 For the strong ties between Great Britain and the League of Nations, see Mark Mazower, Enchanted Palace: The End of Empire and the Ideological Origins of the United Nations (Princeton: Princeton University Press, 2009).

45 Robson, States of Separation; for contemporary documentation, see e.g., "The Settlement of the Assyrians: A Work of Humanity and Appeasement," League of Nations, Geneva (1935), http://www.atour.com/government.

$46 \quad$ Wigram, The Assyrians, 11.

47 Wigram, The Assyrians, 177.

48 Wigram, The Cradle of Mankind, 309. This is the only place where Wigram quotes Tylor's Anthropology, but it is clear that his work has infused much of Wigram's ideas on human history and culture. For the idea of "survivals", see Tylor, Anthropology, 15-16, 411; for a discussion of Tylor's work on religion, see Ivan Strenski, Thinking About Religion: An Historical Introduction to Theories of Religion (Oxford: Blackwell Publishing Ltd., 2006), 91-116, mostly based on Tylor's earlier work (Religion in Primitive Culture, 1873). 
vivals play an important role, the term "survival" mainly refers to things that no longer constitute a vital part of contemporary society. Rereading Wigram's work with this in mind, his use of the term survival in his post-war works suggest that he became even less optimistic about the chances for modern Assyrians to transcend the role of "a strange survival" than he had been before the war. ${ }^{49}$ The Assyrians had become an object of study rather than a living reality. In 1929, indeed, much of what was picturesque had disappeared and the situation had changed for the worst, leaving little hope for the kind of settlement that would ensure national survival and further development. Wigram writes:

If the nation is to survive at all, it must be as no more than an element in the Kingdom of Iraq, where its Church life may be respected, but must alter in new conditions, and any political individuality that it had preserved through the ages must of necessity be dissolved in the life of a larger whole.

One may regret the passing of a picturesque and ancient survival, but there is no means of preserving it. ${ }^{50}$

With these lines that merge the political, the cultural-anthropological, and the personal, Wigram refrains from actively seeking to preserve the Assyrian nation as it was before the war, but rather to put it on record by describing their religion and traditions. That is what needs to be preserved in order to better understand the history of Christianity and that of religion more generally, with the Assyrians' political fate being subordinated to the higher demands of empire.

The most painful ambiguity of Wigram's work, therefore, is that his efforts to understand the Assyrians as a nation in their own right, with a historic and religious pedigree that puts them in the premier league of nations, at the same time delegates them to a place in a museum rather than entitle and strengthen them to fully participate in the living and ever-developing reality of the Iraq and the Middle East more generally. This also suggests that Wigram's ongoing advocacy, in which he urges the British to take responsibility for the Assyrians' fate, is no more than an afterthought in trying to pick up the pieces in support of those that survived. Resettlement and incorporation in British Man-

49 See the rather cautious pre-war final lines of The Cradle of Mankind, $35^{8}$ on the future of the Assyrians: "May it be an omen that the date-palm (Babylon's ancient and beautiful emblem of fertility and life) is now springing up anew in every trench of the excavations at Babil". 
date Iraq, including them in the military, providing work and sustenance, all of that cannot, at least according to Wigram's reading of history, contribute to the Assyrians' re-emergence as a nation among the nations.

Wigram's work embodies all the ambiguities of late imperial and colonial missionary involvement. In it, a genuine interest in the history and current situation of "the Assyrians and their neighbours" is deeply implicated in colonial re-interpretations in service of geopolitical and military interests in the region. This ambiguity parallels the missionary activities as such, in their mixture of long-term processes of mutual learning, inter-Christian aid and humanitarian assistance, in the context of personal involvement, albeit sometimes very critically so, with the objectives and larger aims of British imperial and colonial interests in the region. The missions among the Assyrians, as shown by Becker with regard to the American mission and by Coakley with regard to the Anglicans, were also implicated in the emergence of a nationalist reading of Assyrian history-not so much because the missionaries enforced an alien concept of ethno-religious nationalism on unwitting Assyrians, but because discussions of self and nation, of religion and culture, and of rankings of nations and religions in relation to each other, were part and parcel of the intellectual discussions of the day - in Europe, the Americas, Russia, and in the Middle East. Missionaries, who for many Assyrians and other Christians in the periphery of empires provided the first and most important window on larger intellectual trends, thus became a primary source for new communal understandings among the emerging nations of the Middle East. Vice versa, the missionaries were among the first interpreters of non-Western cultures and religions to Western audiences, introducing radically different people with radically different practices and beliefs as part of what indeed was considered a common humanity, even if they mostly were interpreted as ranking lower on generally accepted scales of civilizations. These recursive dynamics, of explaining empire and the wider world to readers in the west, of personal attachment to new groups outside traditional Western allegiances, with ongoing loyalty to the demands of empire and Western global dominance, characterize Wigram's publications on the Assyrians.

In this, he is a representative of a typically British take on these interactions between the local and the global, the Western and the Eastern churches, the past and the present. His commitment to the integration of the Assyrian church into the ecumenical fellowship of churches was part of a wider 
Anglican commitment to playing the role of broker between Western and Eastern churches. Wigram tried to smooth the way for the Assyrian Church that tended to be excluded from the emerging ecumenical consensus of the early 2oth century in ways that American Protestant and French Dominican missionaries were hardly interested in. Wigram also, more explicitly so than his Presbyterian and Dominican colleagues, was implicated in the colonial and imperial aspects of Western presence in the region. While he came to despair independent nationhood of the Assyrians and was critical of British policies in this regard, he kept seeing them as a useful tool for British colonial rule in the region.

Different from Protestant or Catholic missionary authors, Wigram's advocacy for the Assyrians was grounded in a grand historical scheme that made them worthy of British attention. It was their Christian credentials as an ancient church that faithfully kept some of the oldest rituals and beliefs of global Christianity that contributed to this. These Christian credentials, however, were rooted in a yet more prestigious classical world. Wigram positions the Assyrians as part of one of the oldest civilized nations that emerged in the "cradle of civilizations" that is Mesopotamia, a nation that, despite strings of oppressive and uncivilized governments through the ages, had retained some of that preIslamic and pre-Turk purity that the region as a whole had lost or perhaps never quite had.

His eloquent advocacy had little impact on the position of the Assyrians in and from Iraq. Their integration into the Iraqi state failed miserably and most plans for resettlement fell through. The community became divided among those that preferred to make the most of their new Iraqi homes, those that migrated to Europe, Latin America, and the United States, and the small number that from the 193os onwards made their homes in northeast Syria, along the river Khabur. The implicit and explicit humanitarianism of Wigram's advocacy, therefore, yielded no concrete results, not for the Assyrians as a people, not for the Iraqi or Syrian states, and not for individual Assyrians. What his books and pamphlets did achieve, however, was to put the Assyrians in the historical limelight, undergirding their claims to be allowed to the concert of nations as a nation in their own right, with a combined classical-Christian pedigree that few in the region could match. Whereas his literary advocacy was addressed first and foremost to a Western audience, it was among Assyrians that his interpretation of the nation was to have the most long-lasting effects. His books have contributed to the emergence of an Assyrian nation, of the creation and dissemination of concepts of nationhood among Assyrians and non-Assyrians alike. It is by way of these unintended consequences that Wigram has contributed to the survival of a community that was threatened with extinction. 


\section{Bibliography}

\section{Books and Pamphlets by W.A. Wigram}

Wigram, W.A. The Doctrinal Position of the Assyrian or East Syrian Church. London: SPCK, 1908.

Wigram, W.A. An Introduction to the History of the Assyrian Church: Or the Church of the Sassanid Persian Empire, 100-640. London: SPCK, 1910.

Wigram, W.A. The Cradle of Mankind: Life in Eastern Kurdistan. London: A. \& C. Black, 1914; 2nd ed. London: A. \& C. Black, 1922.

Wigram, W.A. Intercommunion with the Assyrian Church. London: Faith Press, 1920.

Wigram, W.A. Our Smallest Ally: A Brief Account of the Assyrian Nation in the Great War. London: SPCK; New York: Macmillan, 1920.

Wigram, W.A. The Assyrian Settlement. London: SPCK, 1922.

Wigram, W.A. The Cradle of Mankind: Life in Eastern Kurdistan. 2nd ed. London: A. \& C. Black, 1922.

Wigram, W.A. The Separation of the Monophysites. London: Faith Press, 1923.

Wigram, W.A. The Assyrians and Their Neighbours. London: G. Bell \& Sons, 1929.

Wigram, W.A. Hellenic Travel: A Guide. London: Faber \& Faber, 1947.

\section{Other Publications}

Austin, H.H. The Baqubah Refugee Camp: An Account of Work on behalf of the Persecuted Assyrian Christians. London: The Faith Press, 1920.

Becker, Adam. Revival and Awakening:Christian Mission, Orientalism, and the American Evangelical Roots of Assyrian Nationalism (1834-1906). Chicago: Chicago University Press, 2015.

Bradley, Mark, ed. Classics and Imperialism in the British Empire. Oxford: OUP, 2010.

Brooke, Margaret G. Review of The Cradle of Mankind, by W.A. Wigram. International Review of Mission 4, no. 1 (1915): 158-159.

Burkitt, F.C. Review of The Separation of the Monophysites, by W.A. Wigram. Journal of Theological Studies 26, no. 104 (1925): 427-431.

Coakley, J.F. The Church of the East and Church of England: A History of the Archbishop of Canterbury's Assyrian Mission. Oxford: Clarendon Press, 1992.

Coakley, J.F. "Wigram, William Ainger (1872-1953)." In Oxford Dictionary of National Biography, edited by Lawrence Goldman. Oxford: oup, 2004. Available via http:// www.oxforddnb.com/view/article/58374.

Donabed, Sargon George. Reforging a Forgotten History: Iraq and the Assyrians in the Twentieth Century. Edinburgh: Edinburgh University Press, 2015.

Gaunt, David. Massacres, Resistance, Protectors: Muslim-Christian Relations in Eastern Anatolia during World War I. Piscataway, NJ: Gorgias Press, 2006.

Hellot-Bellier, Florence. Chroniques de massacres annoncés: Les Assyro-Chaldéens d'Iran en du Hakkariface aux ambition des empire, 1896-1920. Paris: Geuthner, 2014. 
Husry, Khaldun S. “The Assyrian Affair of 1933." Int. J. of Middle East Studies 5, no. I (1974): 161-176, and no. II: 344-36o.

Joseph, John. The Modern Assyrians of the Middle East: Encounters with Western Christian Missions, Archeologists, and Colonial Powers. ScM 26. Leiden: Brill, 200o, revised.

Kaufman, Asher. Reviving Phoenicia: The Search for Identity in Lebanon. London \& New York: I.B. Tauris, 2002.

League of Nations. "The Settlement of the Assyrians: A Work of Humanity and Appeasement." Geneva, 1935. http://www.atour.com/government.

Lewis Shedd, Mary. The Measure of a Man: The Life of William Ambrose Shedd, Missionary to Persia. New York: George H. Doran, 1922.

Lewy, J. Review of The Cradle of Mankind: Life in Eastern Kurdistan, by W.A. Wigram. Orientalistische Literaturzeitung 35 (1932): 576.

Mazower, Mark. Enchanted Palace: The End of Empire and the Ideological Origins of the United Nations. Princeton: Princeton University Press, 2009.

Mueller, H. "The League of Nations, A-Mandates and Minority Rights during the Mandate Period in Iraq (1920-1932)." In Modernity, Minority, and the Public Sphere:Jews and Christians in the Middle East, edited by S.R. Goldstein-Sabbah and H.L. Murrevan den Berg, 258-283. LSIS 4. Leiden: Brill, 2016; Open Access; Dor: 10.1163/9789oo4 323285 .

Murre-van den Berg, Heleen. From a Spoken to a Written Language: The Introduction and Development of Literary Urmia Aramaic in the Nineteenth Century. De Goeje Fund 28. Leiden: NINO, 1999 .

Murre-van den Berg, Heleen. "William McClure Thomson's The Land and the Book (1859): Pilgrimage and Mission in Palestine." In New Faith in Ancient Lands: Western Missions in the Middle East in the Nineteenth and Early Twentieth Centuries, edited by Heleen Murre-van den Berg, 43-63. SCM 32. Leiden: Brill, 2006.

Murre-van den Berg, H.L. "Light from the East (1948-1954) and the De-Territorialization of the Assyrian Church of the East." In Religion beyond its Private Role in Modern Society, edited by W. Hofstee and A. van der Kooij, 115-134. Leiden: Brill, 2013.

Murre-van den Berg, Heleen. "Writing Assyrian History: The Military, the Patriarch and the British in Yaqu bar Malek Ismael's Assyrians in Two World Wars (Tehran 1964)." In Sayfo 1915: An Anthology of Essays on the Genocide of Assyrians/Aramaeans during the First World War, edited by Shabo Talay and Soner O. Barthoma, 213-23o. Gorgias Eastern Christian Studies 5o. Piscataway, NJ: Gorgias Press, 2018.

O'Flynn, Thomas S.R. The Western Christian Presence in the Russias and Qājār Persia, c.1760-c.1870. SCM 47. Leiden: Brill, 2017.

Project Canterbury. "Intercommunion with the Assyrian Church by William Ainger Wigram, D.D.” Accessed March 30, 2018. http://anglicanhistory.org/orthodoxy/wigr am/assyrian192o.html.

Robson, Laura. States of Separation: Transfer, Partition, and the Making of the Modern Middle East. Stanford: University of California Press, 2017. 
Rouse, Ruth. Review of The Cradle of Mankind, by W.A. Wigram. The Muslim World 4, no. 4 (1914).

Stafford, R.S. The Tragedy of the Assyrians. London: George Allen \& Unwin LTD, 1935. Strenski, Ivan. Thinking About Religion: An Historical Introduction to Theories of Religion. Oxford: Blackwell Publishing Ltd., 2006.

Ticktin, Miriam. "Humanity as Concept and Method: Reconciling Critical Scholarship and Empathetic Methods." Review of Bread from Stones: The Middle East and the Making of Modern Humanitarianism, by Keith David Watenpaugh. Comparative Studies of South Asia, Africa and the Middle East 37, no. 3 (2017): 6o8-613.

Tylor, Edward Burnett. Anthropology: An Introduction to the Study of Man and Civilization. London: Macmillan and Co. 1881, $1896^{2}$.

Watenpaugh, Keith David. Bread from Stones: The Middle East and the Making of Modern Humanitarianism. Berkeley: University of California Press, 2015.

Zubaida, Sami. "The Fragments Imagine the Nation: The Case of Iraq." Int. J. of Middle East Studies 34, no. 2 (2002): 205-215. 